\title{
Seismic Analysis of Soft Storey Buildings Considering Structural and Geometrical Parameters
}

\author{
GAURAV JOSHI ${ }^{1}$, K.K. PATHAK ${ }^{2}$ AND SALEEM AKHTAR ${ }^{1}$ \\ ${ }^{1}$ Department of Civil Engineering, UIT (RGPV), Bhopal, MP \\ ${ }^{2}$ Department of Civil and Environmental Engineering, NITTTR, Bhopal, MP
}

Corresponding author E-mail: kkpathak1@ rediffmail.com

\begin{abstract}
Soft storeys in a high rise building play an important role on its seismic performance. At the soft storey level, there is a discontinuity in the rigidity of the structure due to lack of infill walls or due to variation in floor height. It is this continuity which is the cause of structural failure of multi stored buildings under earthquake loads. In this study, seismic analysis of soft storey building frames have been carried out considering 3 building plans, 15 soft storeys cases and 20 load combinations. Soft storeys have been created by varying the floor heights and effect of infill is ignored. In this way, total 45 frames are analysed. STAAD.pro software has been used for analysis purpose. Results are collected in terms of max. moment, max. storey displacements, max. shear force, max. axial force and max. drift, which are critically analysed to quantify the effects of various parameters .
\end{abstract}

Keywords: Seismic; Maximum moment; Storey displacement; Shear force; Axial force; Drift

\section{INTRODUCTION}

Buildings are classified as having a "soft storey", if that level is less than 70\% as stiff as the floor immediately above it, or less than $80 \%$ as stiff as the average stiffness of the three floors above it. Often, open-ground-storey buildings are called soft-storey buildings, even though their ground storey may be soft and weak. Generally, the soft or weak storey usually exists at the ground storey level, but it could be at any other storey level. Soft storey buildings, having first storeys much less rigid than the storeys above are particularly susceptible to earthquake damage because of large, unreinforced openings on their ground floors. Behaviour of soft storey building to seismic forces has to be critically examined considering various geometrical and seismic parameters. Some of the prominent literature on the topic are as follows:

Journal on Today's Ideas Tomorrow's Technologies, Vol. 1, No. 2, December 2013 pp. $73-84$

\section{CHITKRAR 童 UNIVERSITY}

C2013 by Chitkara University. All Rights Reserved. 
Joshi, G. Pathak, K.K. Akhtar, S.
Ari Wibowo, et. al (2010) concluded that precast soft storey system have sufficient displacement capacity for lower seismic regions, but the performance was considered marginal for higher seismic regions. Plumier, et. al (2005) worked towards promoting safety without too much changing the constructional practice of reinforced concrete structures. He observed that most frequent failure mode of reinforced concrete (R.C.) moment-frame buildings was the so called soft storey mechanism. Mo and Chang (1995) described a practical system combining a flexible first storey with sliding frictional interfaces. The system utilized Teflon sliders at the top of the first storey reinforced concrete framed shear walls to carry a portion of the superstructure. Chen and Constantinou (1990) observed that the practical system deliberately introduces flexibility to the first storey of structures, The system utilised Teflon sliders to carry a portion of the superstructure. Energy dissipation was provided by the first storey ductile columns and by the Teflon sliders. Sivakumaran and Balendra (1994) presented a method of seismic analysis of three-dimensional asymmetric multistorey buildings founded on flexible foundations. The building-foundation system considered in this study was a linear elastic $\mathrm{N}$-storey asymmetric building with a rigid footing resting on the surface of a linear elastic soil half-space. The method of analysis also included the P- $\Delta$ effects, in which the additional overturning moment and torsional moment at each storey due to P- $\Delta$ effects had been replaced by fictitious lateral forces and torques. Zekai Sen (2010) concluded that earthquake hazard assessment of existing buildings was among the most important issues for pre- and post-earthquake warning, preparation, vulnerability, and mitigation works. In any potential earthquake prone area, it was necessary to classify the existing building stoke into different categories according to rapid, simple, reliable, logical and expert view based models and software. Kirac Nevzat, et. al (2011) observed that the negative effects of this weak storey irregularity could be reduced by some precautions during the construction stage. Also, some recommendations were presented for the existing buildings with weakstorey irregularity. Manabu Yoshimura, (1995) conducted nonlinear dynamic response analysis, where strength deterioration was considered in representing member nonlinearity, The analysis was found to reproduce the observed damages well, such as residual displacement, mechanism and damages to members. It was also revealed that if first storey mechanism might occur, the collapse could be unavoidable even for buildings with a base shear strength of as much as $60 \%$ of the total weight. Sivakumaran (1990) proposed a method of analysis for the earthquake response of multi-storey mono-symmetric buildings founded on flexible foundations. The analysis also included the sway $(P-\Delta)$ effects. Vipul Prakash (2004) described the prospects for Performance 
Based Engineering (PBE) in India. He listed the pre-requisites that made the emergence of PBE possible in California, compared the situation in India and discussed the tasks and difficulties for implementing PBE in India. In India, the criteria for earthquake resistant design of structures are given in IS 1893, published by the Bureau of Indian Standards (BIS). IS 1893-2002 reduced the number of seismic zones to four by merging zone I with zone II and adopted a modified CIS-64 scale for seismic zoning and dropped references to the MMI scale.

In this paper, seismic analysis of soft storey buildings considering structural and geometrical parameters have been carried out using STAAD. PRO software. Soft storeys have been created by increasing the floor heights. Effect of infill has been ignored. Results, in terms of moment, displacement, shear force, axial force and drift are critically examined and salient conclusions are drawn.

\section{STRUCTURAL MODELLING AND ANALYSIS}

\section{(a) Modelling of building frames}

All the building Frames considered are $16 \mathrm{~m}$ x $16 \mathrm{~m}$ in plan area and 10 storey $(\mathrm{G}+9)$.

Height of the buildings are $29 \mathrm{~m}$. Following three types of buildings are accounted-

TYPE-A: Height of soft storey $3.5 \mathrm{~m}$ and depth of foundation $1.5 \mathrm{~m}$

TYPE-B: Height of soft storey $3.7 \mathrm{~m}$ and depth of foundation $1.3 \mathrm{~m}$

TYPE-C: Height of soft storey $4 \mathrm{~m}$ and depth of foundation $1 \mathrm{~m}$

Building plan is shown in Fig.1. Structural models for the three types are shown in Fig.2 to 4. Modeling of the building frames are carried out using the

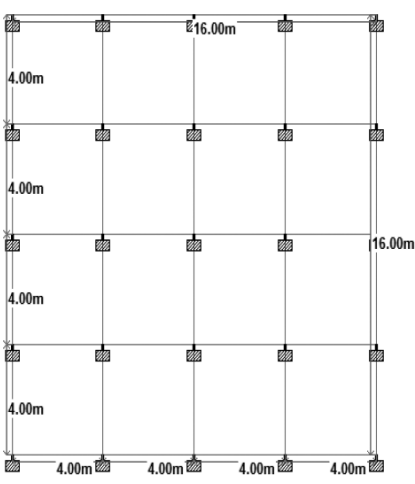

Figure 1: Plan of building

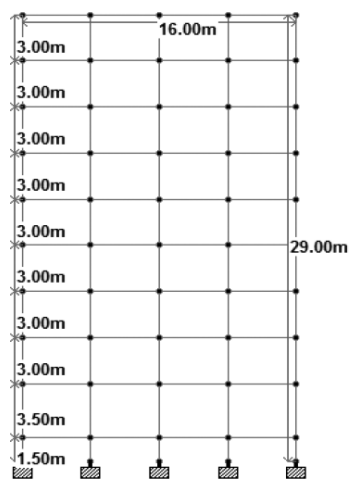

Figure 2: Soft storey building TYPE-1
Seismic analysis of soft storey buildings considering structural and geometrical parameters 
Joshi, G.

Pathak, K.K.

Akhtar, S.

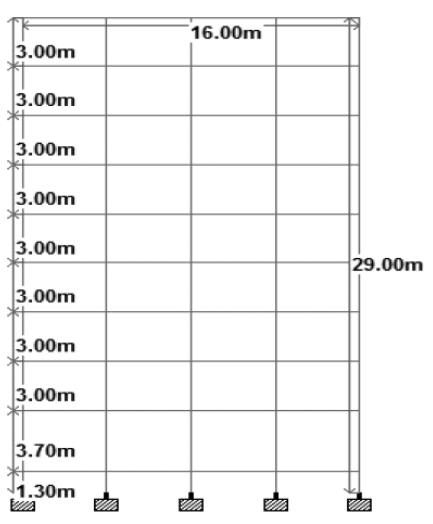

Figure 3: Soft storey building TYPE-2.

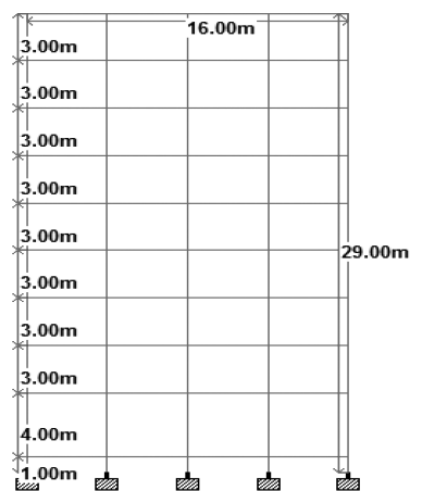

Figure 4: Soft storey building TYPE-3.

STAAD. Pro software. (Ref. 10). Numbers of beams and columns in each type are given in Table 1.

Table 1: No. of beams and columns.

\begin{tabular}{lccc}
\hline Member & Type-1 & Type -2 & Type -3 \\
\hline Columns & 200 & 200 & 200 \\
Beams & 250 & 250 & 250 \\
\hline
\end{tabular}

\section{(b) Soft storey cases}

The following 15 cases have been framed for analysis purpose-

CASE- 1 : Without soft storey

CASE- 2 : Soft storey at first floor

CASE- 3 : Soft storey at second floor

CASE- 4 : Soft storey at third floor

CASE- 5 : Soft storey at fourth floor

CASE- 6: Soft storey at fifth floor

CASE- 7 : Soft storey at sixth floor

CASE- 8 : Soft storey at seventh floor

CASE- 9 : Soft storey at eighth floor 
CASE- 10 : Soft storey at ninth floor

CASE- 11: Soft storey at first and second floor

CASE- 12 : Soft storey at third and fourth floor

CASE- 13: Soft storey at fifth and sixth floor

CASE- 14: Soft storey at seventh and eighth floor

CASE- 15: Soft storey at eighth and ninth floor
Seismic analysis of soft storey buildings considering structural and geometrical parameters

\section{(c) Material and geometrical properties}

Following material properties have been considered in modelling :-

Density of RCC: $25 \mathrm{kN} / \mathrm{m}^{3}$

Density of Masonry: $20 \mathrm{kN} / \mathrm{m}^{3}$

Poisson ratio : 0.17

The column size is $500 \mathrm{~mm} \times 300 \mathrm{~mm}$ and the beam size is $450 \mathrm{~mm} \times 250 \mathrm{~mm}$.

\section{(d) Loading conditions}

Following loading are conducted for analysis:-

1) Dead Loads:

Self wt. of slab considering $150 \mathrm{~mm}$ thick. Slab $=0.15^{*} 25=3.75 \mathrm{kN} / \mathrm{m}^{2}$

Floor Finish load $=1 \mathrm{kN} / \mathrm{m}^{2}$

Water Proofing Load on Roof $=2.5 \mathrm{kN} / \mathrm{m}^{2}$

Masonry Wall Load $=0.25$ x 2.55 × $20=12.75 \mathrm{kN} / \mathrm{m}$

2) Live Loads:

Live Load on typical floors $=2 \mathrm{kN} / \mathrm{m}^{2}$

Live Load on Roof $=1.5 \mathrm{kN} / \mathrm{m}^{2}$

3) Earthquake Loads:

The earth quake loads are derived for following seismic parameters as per IS: 1893(2002)-
a. Earthquake Zone-III
b. Response Reduction Factor : 5
c. Importance Factor : 1
d. Damping : $5 \%$
e. Soil Type: Medium Soil

\section{(e) Structural Analysis}

Structural analysis of the building frames are carried out using STAAD.Pro software (Ref.10). All the columns are rigidly supported at ground and 20 load combinations, given in Table 2, are considered for the analysis purposes. 
Joshi, G.

Pathak, K.K.

Akhtar, S.
Table 2 : Details of load cases.

\begin{tabular}{cc}
\hline Load Case No. & Load cases details \\
\hline 1 & E.Q. IN X DIR. \\
2 & E.Q. IN Z DIR. \\
3 & E.Q. IN -X DIR. \\
4 & E.Q. IN -Z DIR. \\
5 & Dead load \\
6 & Live load \\
7 & $1.5(\mathrm{DL}+\mathrm{LL})$ \\
8 & $1.2(\mathrm{DL}+\mathrm{LL}+\mathrm{EQX})$ \\
9 & $1.2(\mathrm{DL}+\mathrm{LL}-\mathrm{EQX})$ \\
10 & $1.2(\mathrm{DL}+\mathrm{LL}+\mathrm{EQZ})$ \\
11 & $1.2(\mathrm{DL}+\mathrm{LL}-\mathrm{EQZ})$ \\
12 & $1.5(\mathrm{DL}+\mathrm{LL}+\mathrm{EQX})$ \\
13 & $1.5(\mathrm{DL}+\mathrm{LL}-\mathrm{EQX})$ \\
14 & $1.5(\mathrm{DL}+\mathrm{LL}+\mathrm{EQZ})$ \\
15 & $1.5(\mathrm{DL}+\mathrm{LL}-\mathrm{EQZ})$ \\
16 & $0.9 \mathrm{DL}+1.5 \mathrm{EQ}(+\mathrm{X})$ \\
17 & $0.9 \mathrm{DL}+1.5 \mathrm{EQ}(-\mathrm{X})$ \\
18 & $0.9 \mathrm{DL}+1.5 \mathrm{EQ}(+\mathrm{Z})$ \\
19 & $0.9 \mathrm{DL}+1.5 \mathrm{EQ}(-\mathrm{Z})$ \\
20 & $\mathrm{LOAD}$ FOR CHECK \\
\hline & \\
\hline
\end{tabular}

\section{RESULTS AND DISCUSSION}

Results of structural analysis can be described under following heads -

\section{a. Moments in columns and beams}

Comparison of max. bending moment are given in Table 3. Plot of max. moment vs soft storey for all types of buildings is given in Fig.5. It is observed that case 11 and case 14 are most critical for Type A building. It is also observed that case 11 has max. moment at first floor. Case 11 and 12 are most critical for Type B building. Max. moment for Type B building is at first floor for case 11 . Case 2,3 and 5 are most critical for Type $C$ building. Max. moment for Type 
Table 3 : Comparison of Max. Moment $(\mathrm{kN}-\mathrm{m})$.

Seismic analysis of soft storey buildings considering structural and geometrical parameters

\begin{tabular}{ccccccc} 
FIRST & 237.253 & 11 & 243.046 & 11 & 238.493 & 3 \\
SECOND & 232.339 & 11 & 233.458 & 11 & 234.147 & 3 \\
THIRD & 234.679 & 12 & 236.475 & 12 & 234.876 & 4 \\
FOURTH & 234.215 & 13 & 234.164 & 12 & 234.705 & 5 \\
FIFTH & 231.273 & 14 & 234.181 & 13 & 229.754 & 5 \\
SIXTH & 232.332 & 14 & 234.074 & 14 & 229.659 & 10 \\
SEVENTH & 233.636 & 7 & 228.018 & 4 & 223.277 & 2 \\
EIGTH & 225.51 & 2 & 225.437 & 8 & 225.32 & 2 \\
NINTH & 198.795 & 15 & 199.915 & 15 & 201.131 & 10 \\
\hline
\end{tabular}

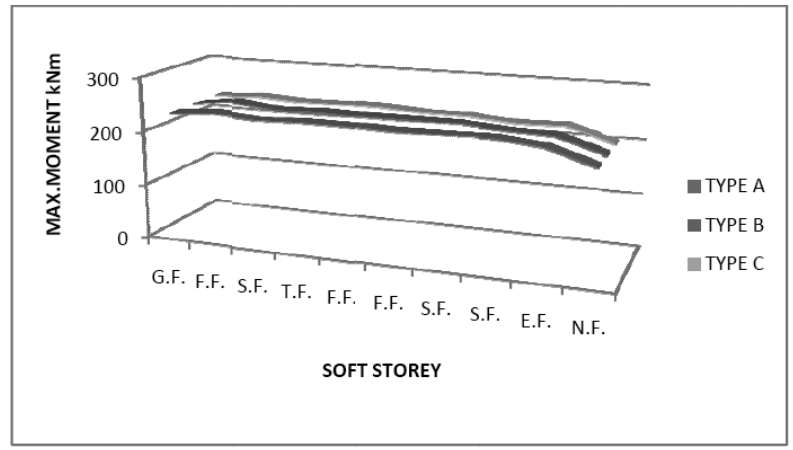

Figure 5 : Max. Moment in buildings

$\mathrm{C}$ building is at first floor for case 3. Max. moment for all types of buildings are at first floor.

\section{b. Storey displacement}

Comparison of max. storey displacement are given in Table 4. Plot of max. storey displacement vs soft storey buildings for all types of buildings is given 
Joshi, G.

Pathak, K.K.

Akhtar, S.
Table 4 : Comparison of Max. Displacement (mm).

\begin{tabular}{ccccccc}
\hline \multirow{2}{*}{ FLOOR } & \multicolumn{2}{c}{ TYPE A } & \multicolumn{2}{c}{ TYPE B } & \multicolumn{2}{c}{ TYPE C } \\
\cline { 2 - 7 } & Displacement & CASE & Displacement & CASE & Displacement & CASE \\
\hline GROUND & 0.414 & 13 & 0.409 & 1 & 0.409 & 1 \\
FIRST & 2.521 & 2 & 2.662 & 2 & 2.955 & 2 \\
SECOND & 4.978 & 11 & 5.376 & 11 & 5.513 & 11 \\
THIRD & 7.02 & 11 & 7.448 & 11 & 7.256 & 11 \\
FOURTH & 9.013 & 12 & 9.532 & 12 & 9.199 & 4 \\
FIFTH & 10.891 & 12 & 11.448 & 12 & 11.025 & 4 \\
SIXTH & 12.533 & 12 & 13.104 & 12 & 12.654 & 4 \\
SEVENTH & 13.906 & 13 & 14.487 & 12 & 14.022 & 4 \\
EIGTH & 14.915 & 12 & 15.503 & 12 & 15.027 & 4 \\
NINTH & 15.5 & 12 & 16.091 & 12 & 15.611 & 4 \\
\hline
\end{tabular}

in Fig. 6. It is observed that case 11 and 12 are most critical for Type A building. Max. displacement is at ninth floor for case 12. Case 12 is most critical for all types of floor for Type B building. Max. displacement for case 12 is at ninth floor. Case 4 and 11 are most critical for all types of floors for Type $\mathrm{C}$ building. Max. displacement for case 4 is at ninth floor. Ninth floor has max. displacement.



Figure 6 : Max. Displacement in buildings

\section{c. Shear force}

Comparison of max. shear force is given in Table 5. Plot of max. shear force vs soft storey for all types of buildings is given in Fig. 7. It is observed that case 
Table 5 : Comparison of Max. Shear force $(\mathrm{kN})$

\begin{tabular}{lllllll}
\hline & TYPE A & \multicolumn{3}{c}{ TYPE B } & \multicolumn{3}{c}{ TYPE C } \\
\cline { 2 - 7 } FLOOR & $\begin{array}{l}\text { Shear } \\
\text { Force }\end{array}$ & CASE & $\begin{array}{l}\text { Shear } \\
\text { Force }\end{array}$ & CASE & $\begin{array}{l}\text { Shear } \\
\text { Force }\end{array}$ & CASE \\
\hline GROUND & 202.283 & 2 & 202.886 & 2 & 202.912 & 2 \\
FIRST & 206.672 & 11 & 209.681 & 11 & 206.994 & 3 \\
SECOND & 202.475 & 12 & 203.721 & 12 & 204.186 & 4 \\
THIRD & 200.646 & 12 & 202.636 & 12 & 200.948 & 5 \\
FOURTH & 200.437 & 4 & 201.087 & 8 & 200.437 & 4 \\
FIFTH & 201.327 & 5 & 201.315 & 5 & 201.296 & 5 \\
SIXTH & 201.335 & 5 & 201.412 & 2 & 201.377 & 2 \\
SEVENTH & 199.815 & 7 & 199.801 & 7 & 199.734 & 2 \\
EIGTH & 199.818 & 2 & 199.791 & 2 & 199.75 & 2 \\
NINTH & 194.28 & 15 & 195.461 & 15 & 196.602 & 10 \\
\hline
\end{tabular}

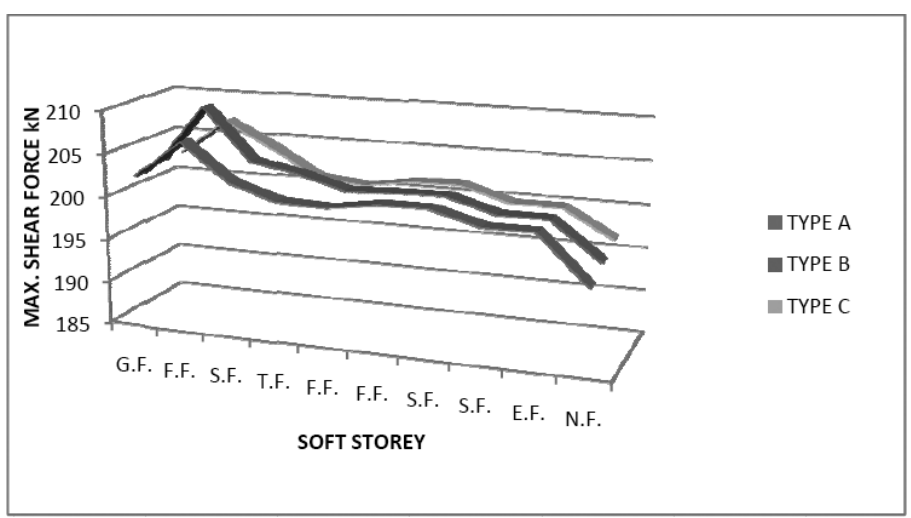

Figure 7 : Max. Shear force in buildings

5 and 12 are most crucial for Type A building and max. shear force is for case 11 at first floor. It is observed that case 2 and 12 are most crucial for Type B building. Max. shear force for Type B building is at first floor in case 11. Case 2 and 5 are most crucial for Type $\mathrm{C}$ building. Max. shear force is at first floor for case 3. Max. shear force for Type A, Type B, and Type C building is at first floor and Type B building has max. shear force among the three. 
Joshi, G.

Pathak, K.K.

Akhtar, S.

\section{d. Axial force}

Comparison of max. axial force is given in Table 6. Plot of max. axial force vs soft storey for all types of buildings is given in Fig. 8. It is observed that max. axial force in Type $\mathrm{A}$ is in case 15 for all types of floor. It is also observed that max. axial force is at ground floor. Max. axial force for Type B building is at ground floor for case 10. Case 10 has max. axial force for all type of floor in

Table 6 : Comparison of Max. Axial force $(\mathrm{kN})$.

\begin{tabular}{|c|c|c|c|c|c|c|}
\hline \multirow[b]{2}{*}{ FLOOR } & \multicolumn{2}{|l|}{ TYPE A } & \multicolumn{2}{|l|}{ TYPE B } & \multicolumn{2}{|l|}{ TYPE C } \\
\hline & Axial Force & CASE & Axial Force & CASE & Axial Force & CASE \\
\hline GROUND & 6142.867 & 15 & 6127.894 & 10 & 6144.234 & 10 \\
\hline FIRST & 5527.688 & 15 & 5552.812 & 15 & 5529.056 & 10 \\
\hline SECOND & 4904.444 & 15 & 4927.208 & 15 & 4905.818 & 10 \\
\hline THIRD & 4286.716 & 15 & 4308.683 & 15 & 4288.098 & 10 \\
\hline FOURTH & 3674.198 & 15 & 3695.245 & 15 & 3675.594 & 10 \\
\hline FIFTH & 3066.453 & 15 & 3086.583 & 15 & 3067.863 & 10 \\
\hline SIXTH & 2463.453 & 15 & 2482.66 & 15 & 2464.895 & 10 \\
\hline SEVENTH & 1781.194 & 15 & 1799.527 & 15 & 1782.547 & 10 \\
\hline EIGTH & 1204.574 & 15 & 1221.074 & 15 & 1207.596 & 10 \\
\hline NINTH & 615.123 & 15 & 623.179 & 15 & 634.391 & 10 \\
\hline
\end{tabular}

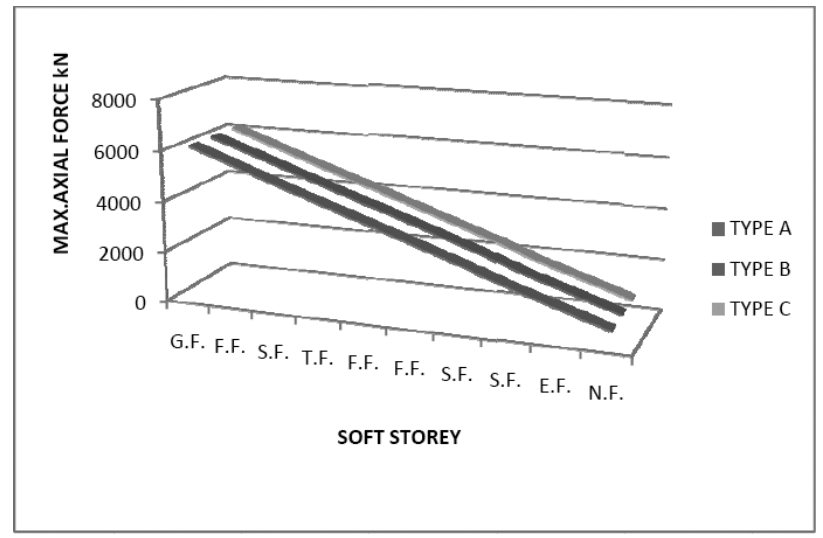

Figure 8 : Max. Axial force in buildings 
Type $\mathrm{C}$ building. Type $\mathrm{C}$ and type $\mathrm{B}$ have maximum and minimum axial force among the three.

\section{e. Drift}

Comparison of max. drift is shown in Table 7. Plot of max. drift vs soft storey for all types of buildings is given in Fig. 9. For type A building, max. drift is in case 11 at second floor. For type B building, max. drift is at third floor for case
Seismic analysis of soft storey buildings considering structural and geometrical parameters

Table 7 : Comparison of Max. Drift (mm).

\begin{tabular}{|c|c|c|c|c|c|c|}
\hline \multirow[b]{2}{*}{ FLOOR } & \multicolumn{2}{|l|}{ TYPE A } & \multicolumn{2}{|l|}{ TYPE B } & \multicolumn{2}{|l|}{ TYPE C } \\
\hline & DRIFT & CASE & DRIFT & CASE & DRIFT & CASE \\
\hline GROUND & 0.584 & 1 & 0.584 & 1 & 0.584 & 1 \\
\hline FIRST & 3.47 & 2 & 3.898 & 2 & 4.6 & 2 \\
\hline SECOND & 3.897 & 11 & 4.434 & 11 & 5.14 & 3 \\
\hline THIRD & 3.882 & 12 & 4.435 & 12 & 5.111 & 4 \\
\hline FOURTH & 3.742 & 13 & 4.268 & 12 & 4.925 & 5 \\
\hline FIFTH & 3.473 & 13 & 4.015 & 13 & 3.69 & 13 \\
\hline SIXTH & 3.09 & 14 & 3.573 & 14 & 3.249 & 14 \\
\hline SEVENTH & 2.51 & 14 & 2.91 & 14 & 2.569 & 14 \\
\hline EIGTH & 1.847 & 15 & 2.169 & 15 & 2.106 & 15 \\
\hline NINTH & 0.992 & 15 & 1.172 & 15 & 1.321 & 10 \\
\hline
\end{tabular}

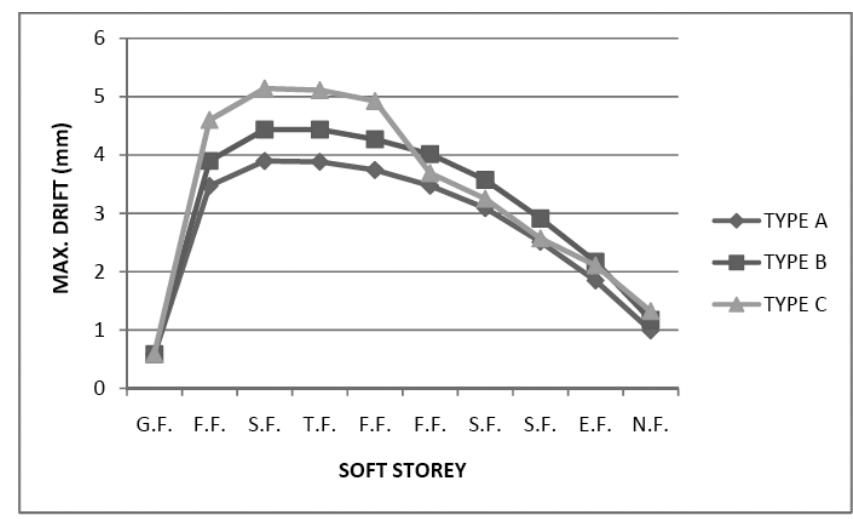

Figure 9 : Max. Drift in buildings 
Joshi, G. Pathak, K.K. Akhtar, S.

12. For type $\mathrm{C}$ building max. drift is at second floor for case 3 . Type $\mathrm{C}$ and type A have maximum and minimum drifts among the three.

\section{CONCLUSIONS}

In this study, performance of building frames are studied considering various geometrical and seismic parameters. Results of this parametric study show that moments and shear forces are always maximum when first storey is soft for all types of buildings. Similarly, axial forces and drifts are also found to depend on structural and geometrical parameters. These results will help design engineers in fast and reliable assessment of the effects of soft storeys.

\section{REFERENCE}

Chen Y.Q., Constantinou M.C., (1990) ,Use of Teflon sliders in a modification of the concept of soft first storey; Engineering Structures, Volume 12, Issue 4, Pages 243-253. http://dx.doi.org/10.1016/0141-0296(90)90023-L

Chopra, A. K., (1995), Dynamics of Structures: Theory and Applications to Earthquake Engineering, Prentice-Hall. Inc., Englewood Cliffs, New Jersey.

Kirac Nevzat, Dogan Mizam, Ozbasaran Hakan, (2011), Failure of weak storey during earthquakes ; Engineering Failure Analysis, Volume 18, Issue 2, Pages 572-581. http://dx.doi.org/10.1016/j.engfailanal.2010.09.021

Mo Y.L., Chang Y.F., (1995), Application of base isolation concept to soft first storey buildings ; Computers \& Structures, Volume 55, Issue 5,Pages 883-896. http://dx.doi.org/10.1016/0045-7949(94)00433-4

Plumier A., Doneux C., Stoychev L., Demarcot T., (2005), Mitigation of soft storey failures of R.C. structures under earthquake by encased steel profiles ; Fourth International Conference on Advances in Steel Structures, Volume 2, Pages 1193-1198. http://dx.doi.org/10.1016/B978-008044637-0/50176-1

Vipul Prakash (2004), Whither Performance-Based Engineering in India, ISET Journal of Earthquake Technology, 41(1), pp. 201-222.

Sivakumaran K.S., Balendra T., (1994), Seismic analysis of asymmetric multistorey buildings including foundation interaction and P- $\Delta$ effects, Engineering Structures, Volume 16, Issue 8,Pages 609-624.

Sivakumaran K.S.,(1990), Seismic analysis of mono-symmetric multi-storey buildings including foundation interaction ; Computers \& Structures, Volume 36, Issue 1, Pages 99-107.

Sen Zekai, (2010), Rapid visual earthquake_hazard evaluation of existing buildings by fuzzy logic modeling ; Expert Systems with Applications, Volume 37, Issue 8, Page 5653.

User's manual STADD. PRO. software, 2013.

Yoshimura Manabu, (1997), Nonlinear analysis of a reinforced concrete building with a soft first storey collapsed by the 1995 Hyogoken-Nanbu earthquake ; Cement and Concrete Composites, Volume 19, Issue 3, Pages 213-221. 